\title{
THE POLEMIC OF CHARGING INTEREST (RIBA) AMOUNG CONVENTIONAL BANK EMPLOYEES
}

\author{
Nanang Bagus Setiawan, Aries Kurniawan, Ilham, Beni Dwi Komara, Nuzulul \\ Fatimah, Tatag Herbayu Latukismo, Heri Cahyo Bagus Setiawan, Riyan Sisiawan \\ Putra
}

\author{
1,2,4,7Entrepreneurship Study Program, Faculty of Economics and Business \\ University Muhammadiyah of Gresik, Indonesia \\ ${ }^{3}$ System Information Study Program, Faculty of Science and Technology \\ UIN Sunan Ampel Surabaya, Indonesia \\ ${ }^{5}$ Institute of Economic Science Mahardhika of Surabaya, Indonesia \\ ${ }^{6}$ Faculty of Economics, University of Krisnadwipayana Jakarta, Indonesia \\ ${ }^{8}$ Management Study Program, Faculty of Economics and Business \\ University of Nahdlatul Ualama Surabaya, Indonesia
}

\author{
gusnhanks@umg.ac.id \\ ariesaja@umg.ac.id \\ benikomara@umg.ac.id \\ ilham@uinsby.ac.id \\ nuzulul.fatimah@stiemahardhika.ac.id \\ tatag@unkris.ac.id \\ hericbs@umg.ac.id \\ riyan_sisiawan@unusa.ac.id
}

\begin{abstract}
This study aims to determine the polemic experienced by a number of conventional bank employees, who know and realize that bank interest is usury or who still believe that bank interest is not usury, because they are only employees who work in banking companies and do not practice usury individually. per individual. From the two attitudes of banking employees in responding to the bank interest usury mentioned above, the study will focus on employees who have the attitude that bank interest is usury, while those who have the opposite attitude are clearly not going to take action to resign from their office. After focusing on anti-antirib banking employees, it was found that from them there were several obstacles to resigning, the first obstacle was internal, namely the lack of support from the family, both the nuclear family and the extended family, while the second obstacle was the repayment of employee loans that they enjoyed before knowing. and realize that bank interest is charging interest or usury (riba). Of the two obstacles or resign constraints will lead to further attitudes for a number of these employees. The attitude of a number of employees who have not received family support, some continue to return to
\end{abstract}


work in a professional manner and some work just to abort their obligations or in other words work not seriously because they are not in accordance with their conscience. While the attitudes of a number of employees who are still in debt, are more varied in attitude, some of them continue to work as usual while waiting for the right moment to pay off their debts, some are still working even though half-heartedly while trying to find a way out so that their debts can be paid off. and some of them are unanimously determined to leave office immediately or borrow a term in the military world, namely by deserting or leaving work by temporarily leaving the debt unpaid, even though they plan to pay it off at a later date. This study used a qualitative research method, namely the collection of indepth interview data with former employees and active banking employees. Researchers also conducted focus group discussions / FGDs (Forum Group Discussion) among bank employees who were anti-microbial but still active and former bank employees who had resigned. As a result, there are five attitudes of banking employees in facing the resign polemic due to bank interest rates in Indonesia. First, employees return to work professionally because they still get salaries from banking companies. Second, employees work only to abort obligations because they are not in accordance with their conscience. Third, employees who are still in debt continue to work professionally while looking for a way to pay off their debts. Fourth, employees who work half-heartedly while looking for ways to pay off loans. Fifth, if their resign application by leaving debt and willing to pay off in installments is refused by the office, they prefer to leave the company unilaterally or go out of business.

Keywords: Riba, Employees; Resign from the Company; Family Supporting; Entangled by Employee Debt 


\section{INTRODUCTION}

Since the issuance of the MUI fatwa concerning Number 1 of 2004 concerning interest (interest / fa'idah), January 24, 2004, since that date it has been reaffirmed that the current practice of earning money has met the criteria for usury that occurred at the time of the Prophet Muhammad, namely usury. nasi'ah. Thus, the practice of wasting money is one form of usury and riba is haram. The practice of interest is haraam, whether it is carried out by banks, insurance, capital markets, pawnshops, cooperatives and other financial institutions or by individuals, thus since the date the MUI fatwa is signed, the decision on bank interest is usury which is forbidden to be final and can be used as a guideline. bemuamalat guidance for Muslims in Indonesia.

The MUI fatwa above in addition to paying attention to the Fatwa of the National Sharia Council (DSN) of the Indonesian Ulema Council (MUI) in 2000 which states that interest is not in accordance with sharia, the Session Decree, Lajnah Tarjih Muhammadiyah in 1968 in Sidoarjo which advised PP Muhammadiyah to seek the realization of a system conception. the economy, especially the Banking Institution that is in accordance with Islamic principles and the Decree of the 1992 National Conference of Ulama and NU Congress in Bandar Lampung which mandated the establishment of an Islamic Bank with an interest-free system.

Noting also the provisions on the prohibition of bank interest by various International Ulema Forums, including: Majma'ul Buhuts al-Islamiyyah in Al Azhar Egypt in May 1965, Majma'al-Fiqh al-Islamiy OIC Countries held in Jeddah on 10-16 Rabiu'ul Awal 1406H / 22-28 December 1985, Majma 'Fiqh Rabithah al-'Alam al-Islamy, Decision 6 Session IX held in Mecca 12-19 Rajab 1406H, Decree of Dar al-Itfa, Kingdom of Saudi Arabia, 1979 and Decision of the Supreme Shariah Court of Pakistan dated 22 December 1999.

Likewise regarding the fatwa of the Tarjih Council and the Tajdid of the Muhammadiyah Central Leadership Number 8 of 2006 stipulating that interest is usury because (1) is an addition to the principal borrowed capital, even though Allah SWT says, And if you repent (from taking usury), then to you is your treasure; (2) Additional binding and contractual nature, while voluntary and non-agreed upon ones do not include usury.

Banking or bank financial institutions are business legal entities that specialize in the financial sector whose business activities are collecting public funds in the form of deposits and channeling them to the public in the form of financing or credit or commonly known as financial intermediary. This is based on Law of the Republic of Indonesia No. 10 of 1998 concerning Banking, the definition of a bank is a business law that collects funds from the public, in this case it can be in the form of savings and channeling credit to the public in the form of loans or financing and / or other forms with the aim of improving people's lives.

\section{LITERATURE REVIEW}




\section{Definition of Riba}

The definition of usury (riba) is to determine interest or add the amount of the loan when the repayment is based on a certain size, in this case, it is usually a percentage of the principal amount charged to the borrower. Based on linguistics, the word riba comes from Arabic which means ziyadah or addition. In other words, the meaning of usury is the additional determination of principal assets or capital in vanity, whether it is carried out in a loan or sale transaction.

Several sources say the meaning of the word Riba, including according to the Big Indonesian Dictionary (KBBI) the meaning of Riba (noun or noun) 1) a moneylender; loan shark; 2) money interest; rent. Then according to the Dictionary of the Central Bank of Indonesia, namely Bank Indonesia and the Dictionary of the Financial Services Authority (OJK), the meaning of the word Riba literally means addition of the principal assets of the loan due to the element of time. In the banking world, this is known as interest. And according to Wikipedia, Riba is the determination of interest or to exaggerate the amount of the loan when repaid based on a certain percentage of the principal amount charged to the borrower.

If we explore more about how to worship and have a religion, especially in Islam, then in Islam it is stated that usury is a practice that is forbidden. Based on Islamic law, the application of interest in a certain amount is usually proxied on conventional bank loans or other financial institutions which is included in the practice of usury. Meanwhile, the types of usury that exist in the community are usury for accounts payable and usury for buying and selling.

The charging interest or usury (Riba), in the Al-Quran has been discussed especially in QS. Al Baqarah: 275, 276, 278 and 279. QS. Ali Imran: 130. QS. Ar Rum: 39. In the Decree of the Fatwa of the Indonesian Ulema Council (MUI) Number 1 of 2004, dated January 24, 2004 regarding interest (interest / fa'idah), it is stated that the law of bank interest is Riba. The above was also confirmed by the Fatwa of the Tarjih Council and the Muhammadiyah Leadership Tajdid Number 8 of 2006, dated 18 June 2006, that Bank Interest is Riba because it is an addition to the principal of the loaned capital.

Nowadays it is very difficult to avoid usury because the practice of usury has become commonplace in people's lives. Both conventional bank interest and financial financial institutions are included in the practice of usury, because when people borrow and from conventional banks, interest will be charged every time they pay the loan installments.

As a devout Muslim, he is obliged to carry out what is ordered and what is prohibited by Allah SWT, including regarding usury as described above, it is stated that bank interest is prohibited because of the practice of usury, and what is the law for bank employees, especially conventional bank employees, in several hadiths it is stated that "Prophet Muhammad SAW cursed those who ate usury, the person who handed it over, the witnesses and the recorders" (Narrated by Bukhari Muslim), "Rasulullah cursed those who ate usury and those who fed usury, two witnesses. and the author "(Narrated by Ahmad, Abu Daud, Ibn Majah \& Tirmidhi). 
Next, there are 4 (four) groups of people who are forbidden based on the above hadith, namely people who enjoy the proceeds of usury or consume (as recipients) of usury, people who give (as giver) usury, recorders of usury and witnesses of usury.

The recipient of usury, any person who is aware of carrying out transactions that generate usury for his / her interests while he knows that the activity is usury, whether through credit, pawning or the exchange of goods or money and others, then all those who take advantage of these activities are legally haram, because they fall into the category the recipient of usury. An example is a person owing money from a bank or other financial and financing institution to buy something or finance something by paying on credit and accompanied by interest.

The giver of usury, personal or institutional using his property or consciously managing other people's assets for an activity that results in the form of usury. Included in this definition is the owner of a financial institution, financing or bank. And the managers are policy makers for an activity that produces usury. A usury registrar is a person who is involved and becomes a conscious registrar of activities that generate usury. This is exemplified by tellers, budget compilers (accountants) and notaries, namely parties who make contracts with usury activities.

A witness for usury, who is involved and becomes a witness in a transaction or agreement that generates usury. Including supervisor (supervisor). While the status of bank employees in other departments or institutions whose activities are related to usury, it is necessary to conduct an in-depth study first. Especially regarding the job description (job discription) of the status of the bank employee. If the work done is part of a process that generates usury, either directly or indirectly, then of course it is haram. Examples are being the leader of a business entity or company, financial planning and management, customer service to receive and provide customer funds in deposit and withdrawal savings transactions as well as supervisors, including any work that produces services related to usury, whether related directly or not.

\section{Employee Conditions Refuse of Riba}

Since the era of openness and ease of internet access, change has become faster and without boundaries, including in religious life. With the increasing spread of religious syiar, especially Islam by ustadz and young scholars who graduated from well-known Islamic colleges from the Middle East and the growing number of online followers and congregations who are present in their offline studies, it will increasingly make Muslims aware of changes in religious life shifting to be more good again.

The understanding that bank interest is prohibited usury is no exception, raising awareness of bankers to see again whether the work they are doing is truly sharia in accordance with the guidance of Islam. The awareness that bank interest is prohibited usury has triggered an increasing number of bankers who are planning to leave their jobs or better known as resigning migrants from ribawi institutions. Furthermore, problems will arise from various sides, both from the side of banking companies and also from the side of employees who understand bank interest usury and their families. While employees who still believe that bank interest is not usury, because they are only 
employees who work in banking companies and do not practice usury individually individually, have not been subject to research discussion because they are not among employees planning to resign migrations.

For this research, it is focused on the employees who understand that bank interest usury is usury that is haram who plans to resign from a banking job. Judging from the constraints faced by prospective banking resigners, we should first understand from their internal side, namely from the side of bank employees. The obstacles are divided into 2 (two) factors. The first is the internal factor of supporting the family, namely the lack of support for the family, both the nuclear family and the extended family, while the second obstacle is the factor of repaying employee loans that they enjoyed before knowing and realizing that bank interest is Riba (usury).

The two inhibiting factors or resign constraints above will lead to further attitudes for a number of these employees. The attitude of a number of employees who have not received family support, is further divided into 2 (two), the first way of behaving is that employees keep returning to work professionally and the second way of behaving is that employees who work just abort their obligations or in other words work not seriously because is not in accordance with his conscience. While the attitudes of a number of employees who are still in debt, are more varied in attitude, consisting of 3 (three), the first way of behaving is that employees continue to work as usual while waiting for the right moment to pay off their debts, the second way to behave is permanent employees. work even though half-heartedly while trying to find a way out so that the debt can be paid off and the third way of behaving is an employee who is unanimously determined to immediately leave the office or borrow a term in the military world, namely by deserting or leaving work by temporarily leaving the debt that has not paid off, even though they plan to pay it off at a later date.

This study used a qualitative research method, namely the collection of in-depth interview data with former employees and active banking employees. Researchers also conducted focus group discussions / FGDs (Forum Group Discussion) among bank employees who were anti-microbial but still active and former bank employees who had resigned. As a result, there are five attitudes of banking employees in facing the resign polemic due to bank interest rates in Indonesia.

First, employees return to work professionally because they still get salaries from banking companies. Second, employees work only to abort obligations because they are not in accordance with their conscience. Third, employees who are still in debt continue to work professionally while looking for solutions to pay off their debts. Fourth, employees who work half-heartedly while looking for ways to pay off loans. Fifth, if their resign application by leaving debt and willing to pay off in installments is refused by the office, they prefer to leave the company unilaterally or are absent, but will still commit to paying off their debt in installments.

\section{RESEARCH METHODS}


Based on the object of research, both place and source of data, this research is included in the category of field research, this field research is mainly based on research in the field or field (Kartono, 1996: 47). This research uses a phenomenological approach, meaning 1) personal experience or phenomenological experience of a person and 2) a study of one's main consciousness and perspective.

The aim of this study is "to understand the experience from the participants' point of view" (Leedydan Ormrod, 2001: 157). The focus is on participants' perceptions of the event or situation and on the study of causes to answer questions of that experience. The essence of this research is the search for meaning that underlies the central basis of experience and deliberate consciousness in which experiences contain outward appearances and inward awareness based on memories, images and meanings "(Creswell, 1998: 52).

The data collection method is through long interviews (1-2 hours) to understand and interpret participants' perceptions about the meaning of an event. The procedural format is to write research questions that explore the meaning of experience, conduct interviews, analyze data to find groups of meaning, and end with a report that adds to the reader's understanding of the essential structure of experience. This study collected data that led to the identification of common themes in people's perceptions of their experiences.

The approach of this research is qualitative, namely research that aims to understand the phenomenon of something experienced by the subject, for example research on behavior, perception, motivation, action, in an olistic way by means of descriptions in the form of words and language, in a natural context by utilizing various natural method. Descriptive research is a study that seeks to collect information about a theme, symptom or situation according to what it is to find the broadest possible knowledge of the object of research. Descriptive research is generally carried out with the main objective, namely to systematically describe the facts and characteristics of the object or subject under study accurately. (Sukardi, 2003: 157).

The data collection technique in this study was by conducting direct and in-depth interviews. In-depth interviews are personal so that it is hoped that the informants will reveal hidden information through certain topics.

Because this technique is personal, the ability to capture the informants' expressions is also subjective. And interviews are also conducted in an unstructured manner so that the information conveyed by the informants is not processed, but is information as it is.

In addition to interviews, data collection techniques are carried out by observation and documentation methods. Observations were made directly at the location of the research site. Observations are made to understand the patterns of attitudes and behavior in the interactions carried out by the informants. The names of the informants that were written were not their real names. Meanwhile, documentation is done by collecting documents that provide supporting information relating to the research objectives.

The informants in this study were both active and inactive bank employees. Some of the interviewees were in a conventional bank environment, this was to obtain a 
comprehensive approach to the view of usury which was another trigger for a reduction in the number of banking employees.

\section{RESULTS AND DISCUSSION}

Constraints for resigners to migrate to banking employees are caused by two factors, namely factors supporting family and employee debt factors. For family supporting factors, it usually occurs when one family does not agree on bank interest rates, one partner or other family member still puts forward the logic of life, about how the future of the family and children is after resigning, about fulfilling economic needs, Regarding a lifestyle that is already high, causing a polemic for employees planning to resign to move to banking, if the husband / wife is determined to resign while the wife / husband does not understand the mindset of their spouse, this condition will occur.

Whereas for the second factor, namely employee debt, this factor is also quite complicated and takes emotion and energy in dealing with it, because not every employee who will resign has enough assets or budget to pay off his loan.

From the results of interviews with several active employees who are planning to resign, employees who are in the process of resigning, and former xbanks, and the research objective is only to examine employees who plan to resign but have not yet happened, while employees who have passed resign without any constraints the two factors above were not discussed in the study. This, obtained results as described below.

Employees who have understood and realized that bank interest is prohibited usury, they plan to resign from banking jobs or known as resign banking migrations. However, it is constrained by resistance from the family, both the nuclear family consisting of the wife / husband and children as well as the extended family, namely the parents or parentsin-law and the employees' relatives. The employee's family does not understand bank interest usury and believes that bank interest is not a part of the prohibited usury so that the employee's family insists that the employee continue to work in the banking sector and no longer needs to discuss resigning because of usury. On average, their families strongly refuse and even some couples threaten to separate if the employee resigns.

From the first facts experienced by the aforementioned employee who plans to resign but is constrained by supporting their family, there are two attitudes of the employee concerned. The first attitude is that the employee gives up trying to understand the current condition of his family by continuing to return to work professionally because they still get a salary from a banking company, so that the resign plan becomes adrift and tends to cancel or even forget about it, even though there is an inner war. conscience.

Meanwhile, the second attitude of employees who plan to resign but are constrained by supporting the family is that the employee continues to return to work as usual due to the condition of his family who is fighting back but by working half-heartedly because it is no longer in accordance with his conscience, and will slowly continue to try to provide understanding to family about bank interest usury, the steps taken by employees with this second attitude are to look for other alternatives by trying to find a replacement job even 
though at the beginning with lower salaries or starting to pioneer in an entrepreneurial way while waiting for the right time to renegotiate with his family, the average of the employees who acted second is the goal is really resign, it's just a matter of time.

Furthermore, the second fact experienced by the aforementioned employee who plans to resign but is financially constrained, namely not being able to pay off employee debts, there are three attitudes of the employee concerned. The third attitude of employees who plan to resign, because employees have not been able to pay off their debts, the attitude taken is to return to work professionally because they still receive salaries from banking companies, on average, those who behave in this way tend to overstate and even forget about the resign plan, think too much debt that must be repaid and thoughtlessly to find other alternatives.

So what is the attitude of the fourth employee planning to resign? What they do is by negotiating with the head of the work unit and applying for relief so that they are allowed to resign with the remaining debt to be settled in installments each period. If this negotiation is deadlocked, the attitude taken is to return to work but half-heartedly, only abort the obligation and keep trying to find a way out so that the debt can be paid off before the resign decision is signed by the company leadership. The average employee with this attitude will get results according to their business, namely they are still allowed to resign with the debt in full, but only a matter of time, that is, the resignation will be delayed one to five years.

There is one more attitude that is classified as reckless among banking resigners in facing financial constraints, namely the inability to pay off the debt before resigning, if the negotiations submitted to the head of the work unit are resigning by leaving debt but committed to making repayments or payments in installments according to the specified period not approved, then their attitude and steps are frontal and out of line by means of absent from work or desertion. However, he will still be responsible for the debt in the banking company.

\section{CONCLUSIONS AND SUGGESTIONS}

Based on the results of the study, it shows that the understanding of bank interest usury is prohibited usury, more and more it is appearing among banking employees who understand and are aware of it. However, before the submission is formally submitted to the company, they consolidate internally, especially with their families and also see their financial condition in order to pay off debts of employees who are still their responsibility.

From the resign plan, there are two inhibiting factors, the first is internal out of the core and the extended family of employees who fight so that the employee does not apply for a banking resign because bank interest usury is not prohibited by religion as intended in the Holy Quran. still believe that they only work in a banking institution so that they are not directly involved in the usury process, they are only paid employees.

While the second obstacle comes from the many remaining employee debts that they have to pay and pay off, while they are not able to pay it at this time, some of them are 
negotiating for postponement of repayment by installments but the company can terminate the resign permit, but the company definitely refuses, apart from because the company does not want to lose its employees, the company will also bear the risk of not paying the company's receivables in the form of resigned employee debts.

If seen from the attitude of employees who plan to resign banking, it can be concluded that there are five attitudes, the first is that they are constrained by family support, they are returning to work professionally because they feel they are being paid by the banking company by previously understanding the resistance of their families if the employee resigns. Most of them never managed to resign.

The second attitude is that they are constrained by supporting their families, they are back to work half-heartedly because they feel they are not in accordance with their conscience, but they still try to find other alternative jobs even though at the beginning the salary is below the bank salary or they start to pioneer entrepreneurship so that at that time It is appropriate to re-apply for resignation, thus the employee has bargain negotiations with the family, on average of them are able to resign even though it is only a matter of time, namely the time of resigning to be delayed one to five years.

The third, namely the attitude of employees who are constrained by financial factors in paying off company debts, before they formally submit a resign application, they negotiate with the head of the work unit about postponing debt repayment by periodically repaying but the company allows the resign application.

Because the company does not allow postponement of debt repayment, among these employees will take the attitude that employees return to work professionally because they feel they are being paid by a banking company, on average they never succeed in resigning because they never try to reduce their debt balance

For the fourth attitude of employees who are negotiating for postponement of deadlock debt repayment, the attitude taken is to return to work but half-heartedly, only aborting obligations and still trying to find a way out so that the debt can be paid off before the resign decision is signed by the company leadership. The average employee who has this attitude will get results according to his business, namely resigning with the debt in full, but only a matter of time, that is, the resignation becomes one to five years back.

And the fifth attitude of employees who have deadlocks on postponement of debt repayment before resigning, namely the attitude that tends to be reckless among banking resigners, namely that they behave and step frontally and get out of the proper way by absent from work or desertion. However, they are still committed to paying their debt installments even though the schedule has been delayed.

Employees who act like this are actually faster in the repayment process by gradually lowering their debt periodically, it turns out that Allah's risk is broad from any door He wants as long as his people have the intention and always try hard to achieve his life goals in the world, which is only for worship Allah SWT. Suggestions from researchers Hopefully, the relationship between active banking employees and xbank will continue to be well maintained until the end of time. Aamiin Yaa Rabb. 


\section{REFERENCES}

[1] A Kurniawan, M Asharudin. (2019). Small and Medium Enterprises (SMEs) Face the Digital Market. LIP FEB UMM

[2] F. Almada-Lobo, The Industry 4.0 revolution and the future of Manufacturing Execution Systems (MES), Journal of Innovation Management JIM 3, 4 (2015) 16-21. 
[3] F. Rennung, C.T. Luminosu, A. Draghici, Service Provision in the Framework of Industri 4.0, SIM 2015 / 13th International Symposium in Management, Procedia - Social and Behavioural Sciences 221 ( 2016 ) 372 - 377.

[4] J. Lee, H.A. Kao, S. Yang, Service innovation and smart analytics for Industry 4.0 and big data environment, Product Services Systems and Value Creation. Proceedings of the 6th CIRP Conference on Industrial Product-Service Systems, Procedia CIRP 16 (2014) $3-8$.

[5] Kartono. Kartini,1996, Pemimpin dan Kepimpinan.CV. Rajawali.Bandung.

[6] K.D. Thoben, S. Wiesner, T. Wuest, Industrie 4.0 and Smart Manufacturing- A Review of Research Issues and Application Examples, International Journal of Automation and TechnologyVol.11 No.1, 2017 4-16.

[7] K. Sipsas, K. Alexopoulos, V. Xanthakis, G. Chryssolouris, Collaborative maintenance in flow-line manufacturing environments: An Industri 4.0 approach, 5th CIRP Global Web Conference Research and Innovation for Future Production, Procedia CIRP 55 (2016) 236-241.

[8] M. Brettel, N. Friederichsen, M. Keller, How Virtualization, Decentralization and Network Building Change the Manufacturing Landscape: An Industri 4.0 Perspective, International Journal of Mechanical, Aerospace, Industrial, Mechatronic and Manufacturing Engineering Vol:8, No:1, 2014, 37-36.

[9] R. Neugebauer, S. Hippmann, M. Leis, M. Landherr, Industrie 4.0- Form the perspective of apllied research, 49th CIRP conference on Manufacturing systems (CIRP-CMS 2016), 2-7.

[10] Tay, Shu \& Te Chuan, Lee \& Aziati, A. \& Ahmad, Ahmad Nur Aizat. (2018). An Overview of Industry 4.0: Definition, Components, and Government Initiatives. Journal of Advanced Research in Dynamical and Control Systems. 10. 14.

[11] MAK. Bahrin, MF. Othman, NH. Nor, MFT. Azli, Industry 4.0: A Review on Industrial Automation and Robotic, Jurnal Teknologi (Sciences \& Engineering), eISSN 2180-3722 (2016) 137-143.

[12] Moleong, Lexy, J,.2011. Metodologi Penelitian Kualitatif edisi revisi, Remaja Rosdakarya, Bandung.

[13] Poerwadarminta. W.J.S, 2003,Kamus Umum Bahasa Indonesia, Balai Pustaka, Jakarta

[14] Sugiyono, 2008, MetodePenelitianBisnis, Alfabeta, Bandung

[15] https://finance.detik.com/moneter/d-3902718/jumlah-pegawai-bank-terusberkurang. Diakses pada tanggal 26 Januari 2021

[16] https://mmc.tirto.id/image/2019/03/28/karyawan-bank--mild--quita-01.jpg. Diakses pada tanggal 26 Januari 2021

[17] https://tirto.id/saat-digitalisasi-perbankan-menyingkirkan-ribuan-karyawanbank-dkqqq. Diakses pada tanggal 26 Januari 2021

[18] https://finansial.bisnis.com/read/20190321/90/902817/dampak-revolusi-industri40-jumlah-karyawan-cimb-niaga-terus-berkurang. Diakses pada tanggal 25 Oktober 2019 
[19] https://keuangan.kontan.co.id/news/ini-alasan-jumlah-kantor-cabang-dankaryawan-bank-menurun-menurut-bankir. Diakses pada tanggal 26 Januari 2021

[20] https://pengusahamuslim.com/6121-kenapa-aku-resign-dari-bank-syariah-kisahmantan-karyawan-bank-syariah.html. Diakses pada tanggal 26 Januari 2021

[21] https://www.independent.co.uk/news/business/news/fintech-technologybanking-jobs-30-per-cent-cut-replace-citigroup-ceo-vikram-pandita7944016.html. Diakses pada tanggal 26 Januari 2021

[22] https://www.chinadaily.com.cn/a/201909/16/WS5d7f1a20a310cf3e3556ba74.ht ml. Diakses pada tanggal 26 Januari 2021 